\title{
Yeni Dünya Düzeninin Bir Habercisi Olarak Azerbaycan-Ermenistan Çatışmasının Sosyo-Politik Analizi
}

\author{
The Sociopolitical Analysis of Azerbaijan and Armenian Conflict As An Harbinger of A New World \\ Order
}

\author{
Hüsamettin İNAÇ \\ Prof. Dr., Kütahya Dumlupınar Üniversiitesi, İ̈BF, \\ Siyaset Bilimi ve Uluslararası İlişkiler Bölümü, \\ husamettininac@yahoo.com \\ https://orcid.org/0000-0002-6922-2010
}

Makale Başvuru Tarihi: 20.11.2020

Makale Kabul Tarihi: 12.12.2020

Makale Türü: Araştırma Makalesi

\begin{tabular}{|c|}
\hline $\begin{array}{l}\text { Anahtar } \\
\text { Kelimeler: }\end{array}$ \\
\hline Karabă̆ Sorunu, \\
\hline $\begin{array}{l}\text { Azerbaycan- } \\
\text { Ermenistan } \\
\text { Çatışmast, }\end{array}$ \\
\hline $\begin{array}{l}\text { Yeni Dünya } \\
\text { Düzeni, }\end{array}$ \\
\hline Kolektif Güvenlik, \\
\hline $\begin{array}{l}\text { İki Kutuplu Dünya } \\
\text { Düzeni, }\end{array}$ \\
\hline
\end{tabular}

Anahtar

Karabağ Sorunu,

Azerbaycan-

Ermenistan

Yeni Dünya

Düzeni,

Kolektif Güvenlik

Düzeni,

Keywords:
Karabakh Question,
Azerbaijani-
Armenian Conflict,
New World Order,
Collective Security,
Bipolar World
Order,

\section{ÖZET}

İkinci Dünya Savaşı'ndan sonra kurulan iki kutuplu dünya düzeni pek çok bakımdan yıkılmaya yüz tutmuş durumdadır. Bu düzenin oluşturduğu kurumlar itibarını yitirmekte, güç odağı gittikçe doğuya doğru kaymakta, düzenin hegemon gücü olan ABD gittikçe zaylflamaktadır. Bu durum uluslararası arenada çok önceden çıkmış olup henüz çözümlenemeyen ve literatürde "dondurulmuş ihtilaflar" olarak bilinen sorunları yeniden gündeme taşımaktadır. Azerbaycan-Ermenistan çatışması da bu kabil sorunlardan olup yaklaşık yüz yıllık bir maziye sahiptir. Özellikle 1988-1992 arasında Ermenilerin Azerbaycan topraklarını işgali neticesinde sayısı bir milyonu bulan Azerbaycanlı kaçkın, kendi ülkesinde mülteci durumuna düşürülmüştür. 27 Eylül 2020'de Ermenistan'ın sivil Azerbaycan bölgelerine yaptığı saldırılar 44 günlük bir savaşa dönüşmüş, neticede Rusya'nın hakemliğiyle bir ateşkes anlaşması ortaya çıkmıştır. Türkiye'nin de yoğun destek verdiği Azerbaycan, özellikle Karabă̆’da istediğini tam olarak alamamış gibi görünmekle beraber, Birleşmiş Milletler Yüksek Komiserliği'nin (UNHCR) gözetiminde Ermeni ve Azerbaycan vatandaşlarının 1992 öncesi yerleşim yerlerine dönmesi sağlanarak soruna önemli ölçüde çözüm bulunabilecektir. Bu çalışma, söz konusu savaşın Güney Kafkasya başta olmak üzere bölgede ve dünyada jeopolitik yapıyı nasıl değiştirdiğini ve yeni oluşmakta olan düzenin şekillenişine hangi yönde katkı sağlayacă̆ını irdelemeyi amaçlamaktadır.

\section{ABSTRACT}

The bipolar world order which has been established after the-WWII has been collapsing in many respects. Institutions formed by this order lose their reputation, the focus of power has shifted towards the East and the USA as the hegemonic power is gradually weakening. This situation brings back to the agenda that have emerged long ago international arena but have not yet been resolved and known as "frozen conflicts" in the literature. to come to the agenda Azerbaijan and Armenia is one of hese conflicts and has a history about a century. Especially, as a result of 1988-1992 Armenian occupation of Azerbaijani lands, more than one million Azerbaijani citizens turned into figutives within their homelands. The Armenian assaults and aggressions on Azerbaijani settlements and civil citizens which initiated in September 27, 2020 has been transformed into a war that lasted 44-days war and at the end of the day, a ceasefire agreement has been emerged with the Russian arbitration. Azerbaijan supported by Turkey extensively as well, even though it seems she couldn't obtain what she desired compeletely in Karabakh, it is possible to find a solution to the question by enabling the return of Armenian and Azerbaijani citizens on the place which they were in pre1992 under the auspices and observance of the UNHCR. Despite the fact that this agreement was not satisfactory for the sake of Azerbaijani political targets and ideals, the resettlement of Azerbaijani and Armenian people which were forced to replace during the war and the return of displaced people and refugees to previous places before 1992 will contribute to the final solution with large extent. This study aims to elaborate how this war in question has changed the existing geopolitical structure in the region and the World, especially in the South Caucaus and in what direction it will contribute to the reshaping of the world order. 


\section{GIRISŞ: DÜNYA DÜZENİ KAVRAMINA TEORIKK VE TARİHSEL BİR BAKIŞ}

Dünya düzeni kavramı uluslararası ilişkiler disiplininde önemli yer tutan bir kavramdır. Modern anlamda devletlerin oluştuğu ve bu oluşan devletlerarasında münasebetlerin başladığı ilk dönemlerden itibaren ülkelerin sahip oldukları milli güç unsurları ve kapasiteleri aktörler arasındaki güç dağılımını belirler. Bu dağılıma bağlı olarak tek devletin hâkim olduğu, şartlarının bu baskın aktör tarafindan belirlendiği zorunlu bir barış dönemi (pax) olabileceği gibi hiçbir aktörün tek başına domine edemediği kaotik dönemler de yaşanmıştır. Dünya düzeni kavramı çoğu zaman uluslararası sistem kavramıyla birlikte kullanılsa da aslında bu iki kavram farklı olguları ifade etmektedir. Nitekim uluslararası sistem devletlerin birbirleriyle kurdukları ilişkiler üzerinden her birinin icra ettiğgi farklı işlevlere bağlı olarak bir vücudun organları gibi geliştirdikleri organik sistematiğe işaret etmektedir. Öte yandan dünya düzeni kavramı ise, uluslararası ekonomik ve siyasi işbirliği ve işlemleri düzenleyen çeşitli norm ve kurallarla şekillendirilen yapılar sisteminin adıdır. Yapı da; halk, devletler, şirketler, sivil toplum kuruluşları ve çok taraflı kurumlar çerçevesinde oluşan düşünce ve eylem modellerini betimlemek için kullanılan bir kavramdır. Dünya düzeni ve yapıları, hâkim aktörlerin kısa ve uzun dönem güvenlik çıkarlarının yanı sıra hâkim güçlerin değer ve inanç sistemlerine göre şekillenir (Cox 1987:43).

Dünya düzeninin modern yapısal çerçevesi ve bu düzenin şekillendirdiği uluslararası ilişkiler şimdiye dek Vestifalyan ulus-inşa projesine bağlı olarak konumlandırılır. Burada kendisine atıfta bulunulan Vestifalyan dönem, Otuz Yıl Savaşları sonunda 1648'de Vestifalya'da müzakere edilen Avrupa barışın yerleştirilmesi süreciyle başlar. Barış anlaşması ile beraber Hristiyanlar arası iç rekabet nihayete ermiş, kralın kendi topraklarındaki hükümranlığı perçinlemiş ve Katolik ve Protestan ayrımı önemli ölçüde ortadan kaldırılmıştı. $\mathrm{Bu}$ durum toprak kontrolü ihtiyacını artırdı ve bağımsız ulus-devlet sisteminin yaratılması ve takviyesini kolaylaştırdı. Haliyle bu gelişmeler bağlamında dünya düzeni, Vestifalyan ulus-devlet projesi boyunca özgürlük, düzen ve adalet gibi sosyal aktörlerin inanç sistemlerindeki temel öneminin çekirdek değerlerine duyduğu uzun dönem ilgi ile aynı aktörlerin kısa vadeli ulusal güvenlik çıkarları arasında kurulan denge olarak anlaşılabilir (Hettne ve Björn, 2007:74-77).

Toplumda etkinliğini sürdüren siyasi dinamikler ve hegemonya tartışmalarına katılan Gramsci, toplumda pek çok aktörce meşru kabul edilen ve hegemon gücü kazanmak için yeterli siyasi güce sahip olan tarihi blok tarafından hâkim söylemin şekillendirildiğini ifade eder. Ki bu blok, yeni dünya düzenini kuran temel aktördür. Ne var ki farklı sosyal güçler arasında siyasi ittifakla kurulan tarihi blok, alternatif söyleme sahip bir başka hegemonya tarafından yıkılabilir.

Dünya düzeni kavramına farklı bir boyuttan yaklaşan Macar tarihçi ve antropolog Karl Polanyi tarafindan 18 ve 19. Yüzyıl boyunca İngiltere'deki sanayi devrimlerince şekillendirilen siyasi diyalektik, çifte hareket (double movement) olarak tanımlanır (Campbell, 1992:199). Piyasanın yaygınlaştırılması ve sosyal güvenlik ağlarının parçalanması ile özgürlük, düzen ve adalet arasında denge söylemi ilk hareketi oluşturur. Öte yandan toplumun tepkisi ve nefsi müdafaası da farklı bir özgürlük, düzen ve adalet arasında denge söylemi yaratarak ikinci hareketi doğurmuştur. Tarihi bloklar arasında sürdürülen ideolojik mücadelenin neticesinde aktörler arası nihai denge oluşur. Sivil toplum yeterince güçlü değilse rakip söylemler arası savaş kaçınılmaz hale gelir. Vestifalyan ulus-devlet projesine göre; kalkınma ve modernleşme gittikçe artan husumet ortamında devletin koruma kapasitesi ve bekası için elzemdir. Fakirlik ve gelişmemişlik ise, geri kalmışlı̆̆ın neticesidir. Yüksek politika olarak belirlenen güvenlik söylemi, devlet ile vatandaş arasında yapılan sözleşmenin temelini teşkil eder. Öyle ki güvenlik söylemi toplumda tüm söylemlerin önüne geçecek kadar ehemmiyeti haizdir. Zira vatandaş zararlı ve tehlikeli olandan korunmak uğruna özgürlüğünden vazgeçebilir. Nitekim devletin meşruiyeti de vatandaşını güven içinde korunma kapasitesinden kaynaklanır. Buna ilaveten ulusal güvenlik devletin dış çıkarlarıyla içerideki çıkarını savunması arasında bağla açıklanır (Campbell, 1998:66-69). Bu bağlamda refah ve adalet iç istikrar için olmazsa olmaz parametrelerdir. Devlet güvenliği ise devletin egemenlik haklarına saldırıyla ve devletin toprağını korumak için güç kullanımıyla alakalıdır.

Vestifalyan dönemde tehdit ve tehlike algısıyla ortaya çıkan uluslararası anarşi, barışı sürdürmek için umutları azaltan bir güvenlik ikilemi yaratır. Bununla baş etmenin yolu, rakip taraflar arasında güç dengesinin oluşturulmasıdır (Fierke, 2007:44). Her dünya düzeni, uluslararası sistemin önde gelen devletleri arasında güç dengesi ve siyasi oluşumları yansıtan kendine özgü meşrulaştırma şekli ve yönetim tarzıyla kimlik kazanır. Uluslararası ekonomik işbirliği için elzem görülen dünya düzeni, istikrarı üzerinde uzlaşılan kural ve normları tatbik etmek ve müeyyideler koymak için hâkim bir güce ihtiyaç duyar. Tarihsel olarak dünya düzeni liderliği, yumuşak güce dayalı hegemon ve meşru liderlikle yapısal ya da askeri sert güç kullanan zorlayıcı liderlik arasinda denge kurar. 


\section{2. İKİ KUTUPLU DÜNYA DÜZENINIIN SONA ERIŞ̧i}

Tüm bu tarihsel ve teorik arka planı esas alarak değerlendirdiğimizde iki kutuplu dünyanın oluşturduğu düzenin, önemli ölçüde etkinliğini yitirdiğini iddia edebiliriz. Bu durumun en önemli tarihsel dönüm noktaları olarak 1989'da Berlin Duvarı'nın yıkılması, 1990'da Doğu Avrupa'da sosyalizm karşıtı halk hareketlerinin başlaması ve nihayet 1991'de Moskova'da Komünist Parti'nin parçalanmasıyla Sovyet Rusya'nın uluslararası sahneden çekilmesi gösterilmektedir. Haddi zatında "ötekisini” kaybetmiş bir düzenin varlı̆̆ını sürdürmesi beklenemezken öte yandan bu düzeni ayakta tutan kurumlar ve bu kurumların üzerinde yükseldiği değerler sistemi de önemli ölçüde itibarını yitirmişlerdir. Nitekim iki kutuplu dünyada hegemon güç konumunda bulunan $\mathrm{ABD}$, bu konumunu üç enstrüman üzerinden konsolide etmekteydi. Bunların başında dünyanın tüm ihtilaflı ve stratejik önem taşıyan noktalarında varlığını devam ettiren askeri üsler ve Amerikan ordusu gelmekteydi. Öte yandan bu sistemi sürdürmede gerekli olan ekonomik dayanak ve uluslararası rezerv para olarak dolar önemli bir rol oynamaktaydı. Son olarak da düzenin meşruiyetini sağlayan olgu olarak küreselleşme ve onun normatif çerçevesini belirleyen ideoloji olarak neo-liberalizm ön plana çıkmaktaydı (Dedeoğlu, 2008:21-23).

Zaman içerisinde ABD'yi yönetenlerin stratejik hırslarına mağlup olarak 11 Eylül 2001 sonrası Irak ve Afganistan'ı işgal etmeleri, işgalle beraber insan haklarıyla bağdaşmayacak ihlal ve işkencelerin yaygınlaşması ve hiçbir haklı gerekçeye dayanmayan İslami terör kavramı üzerinden medeniyetler çatışmasına yol verilmesi var olan düzenin itibarına ciddi bir biçimde halel getirmişti. Tüm bu gelişmelere paralel olarak IMF'den Dünya Bankasına, Birleşmiş Milletlerden NATO ve Avrupa Konseyine varıncaya kadar uluslararası örgütlerin ideolojik ve adaletsiz bir siyasi tutum belirlemiş olmaları düzeni daha da sorgulanır hale getirmişti. Var olan düzeni meşrulaştıran küreselleşme ve küreselleşmenin ideolojisi olarak neo-liberalizm, adil ve hakkani bir ticari rejim geliştiremediği gibi dünyada çatışmaları sonlandıramadı ve küresel sorunlara küresel çözümler üretemedi. Nihayetinde fakirlik, işsizlik, gelir adaletsizliği, otoriter yapılar, terör, çatışmalar, belirsizlikler ve insan sağlığına yönelik tehditler gibi uzayıp giden problemleri sonlandırabilecek küresel yönetişim modeli geliştirilemedi. Üstüne üstlük çift kutuplu dünyanın ezberleri zaman içerisinde birer birer ikna edici karakterlerini kaybetti. Öncelikle Rusya'nın güçlü bir devlet olmadığı ve ancak ABD’nin izin verdiği kadar varlık alanı bulabileceği ortaya çıktı. Bretton Woods uzlaşının bir gereği olarak petro-dolar kartını elinde tutan ABD'nin petrol fiyatlarını manipüle ederek Rusya'yı bitirebileceği görüldü (Ar1, 2013:45-85). Öte yandan ABD’nin de artık eskisi kadar güçlü olmadığı ve Amerikan karşıtlığı üzerinden farklı kutupların inşa edilebildiği de müşahede edildi. Nitekim ABD'nin ilk Körfez Savaşından itibaren yaptı̆̆ 1 hiçbir operasyonun siyasi hedefine ulaşamadığı da ortaya çıktı. 2008 küresel mali krizi, küreselleşmenin hiç de iddia edildiği gibi muhkem bir kale olmadığını ve ulus-devletlerin müdahaleci karakteri sayesinde krizlerin atlatılabileceğini dünya kamuoyuna deklare etmiş oldu. Nihayet, konvansiyonel silahlar ve demode tehdit algıları üzerine inşa edilmiş olan dünya düzeni yıkılmaya yüz tutmuş durumdaydı.

Korona virüsünün yaygınlaşıp pandemiye dönüşmesi sonrasında uluslararası kamuoyu, küresel siyasetin nasıl şekilleneceği tartışmaları üzerinden yeni bir dünya düzeninin inşasına yönelik tartışmalara çoktan başlamış durumda. Yukarıda tartıştığımız Soğuk Savaş döneminin getirdiği dünya düzeni ve bu düzenin kurum ve kuruluşlarıyla ilgili yaptığımız analiz, Covid-19'un dünya gündemine girmesinden çok daha önce hâlihazır sistemin değişmesini beraberinde getirebilecek zihin altyapının mevcut olduğunu göstermektedir. Zira savaştan galip çıkan ABD'nin oluşturduğu dünya düzenin baştan beri ciddi çelişkiler taşıdığı ve zamanla bu çelişkilerinin birer açmaza dönüştüğü aşikârdır. En başta SSCB'nin gücünün abartılar bir öteki olarak karşı kutba yerleştirilmesi, komünizmin çok büyük bir tehdit olarak ideolojik ayrışmanın yaratılması ve bu düzenin kurum ve kuruluşlarının sadece Amerikan çıkarlarına hizmet edecek şekilde dizayn edilmesi baştan itibaren sorunlu bir küresel sistemin mevcudiyetine işaret etmektedir. Öte yandan 2004 yılında Ortadoğu'daki halkı Müslüman ve Arap olan ülkeleri daha küçük parçalara ayırarak daha kolay sömürmeyi esas alan Büyük Ortadoğu Projesi’nin (BOP) dönemin Dışişleri Bakanı Condoleezza Rice tarafından ilan edilmesi bu dizaynın kırılma noktalarından birisi haline gelmiştir (Dedeoğlu, 2018:32). Nitekim bu projenin hayata yansıtılmasıyla beraber kendisini İslam'la özdeş gören küresel terör örgütleri kurulmuş ve Samuel Huntington'ın Medeniyetler Çatışması tezine hayatiyet kazandırılmıştır. 2008 küresel mali krizi ise küreselleşmenin tüm devletler için vaat edilen pozitif gelişmeyi saplayamadığının ispatı olarak algılanmıştır.

2016 Ocak ayında Trump yönetiminin işbaşına geçtiği ABD, küreselleşme ve neo-liberalizmi baltalayacak politikalar izleyerek ABD'yi korumacı ve ulusalcı politikalara teslim etmiştir. Amerika'yı önceleyen (America First) ve Amerika'yı yeniden büyük kılmayı hedefleyen (MAGA) söylemler, hem ABD'nin hegemon güç olma iddiasını ortadan kaldırmış ve hem de iki kutuplu dünyanın yerini çok kutupluluğa bırakmasını sağlayacak yeni bir eğilim ve yönelim yaratmıştır. 


\section{3. İKİ KUTUPLU DÜNYA DÜZENININ ORTAYA ÇIKARDIĞI PROBLEMLER VE ERMENISTAN- AZERBAYCAN ÇATIŞMASININ TARIHHSEL ARKA PLANI}

Dünyada hegemon güçlerin olmadığı, bölgeselci politikaların hakim hale geldiği ve uluslararası kurumların meşruiyetini yitirdiği bir politik atmosfer, yüz yıl önceki hesapların tekrar görüleceği, donmuş ihtilafların (frozen conflicts) dondurucudan çıkarılacağı ve nihayetinde her devletin kendi hesabını kendi görmek durumunda bırakıldığı kaos ve anarşi döneminin bir işaret fişeğidir aynı zamanda. Tam da bu kabil uluslararası konjonktürün hâkim olduğu bir dönemde Akdeniz, Karadeniz, Balkan, Kafkasya, Ortadoğu ve Avrupa kimliklerini hem jeopolitik ve hem de kültürel olarak bünyesinde barındıran Türkiye, farklı bir stratejik ufuk ve derinlikli dış politikayla bölgesinde yükselen bir figür haline gelmektedir. Öyle ki Karadeniz ve Kafkasya'da söz sahibi olmak isteyen ABD, Türkiye ile işbirliği ve senkron geliştirmek zorundadır. NATO başta olmak üzere uluslararası kurumları güçlendirmek isteyen ABD, Türkiye'nin yardımı ve desteği olmadan bu hedefini başaramayacaktır. ABD ile süper güç olma iddiasındaki Çin'in kapışmasının adı olan Kafkas Baharı, Türkiye'nin hem medeniyet ve hem de jeopolitik olarak çok güçlü olduğu Orta Asya coğrafyasında cereyan edecektir. Yeni Dünya'nın jeopolitik merkezi olarak kabul edilen Akdeniz, Türkiye'nin en uzun sınıra sahip olduğu, Kıbrıs gibi bir adada garantör statüsün koruduğu ve Doğu Akdeniz'de BM'nin tanıdığı meşru Trablus Hükümeti'nin sponsoru olarak rol aldığı bir kültür havzasıdır. Halkı Müslüman olan elli yedi İslam ülkesinde laik, demokratik ve batılı değerlerle mücehhez karakteri ve İslam'la demokrasiyi kendi bünyesinde harmonize ederek iktisadi kalkınmasıyla göz dolduran Türkiye, Ortadoğu için hala bir model ülke konumundadır (Budak, 2019:15).

Ermenistan, 1826-1828 Rus-İran Savaşından sonra Azerbaycan bölgesinin Ruslara teslim edilmesi ve gene Rusya ile girdiği savaşı kaybeden Osmanlı'nın imzaladığı Edirne Anlaşması neticesinde ortaya çıkmış bir proje devlettir. Aynen bu anlaşmayla kurulmuş Yunanistan gibi. Haddi zatında bölgenin toplam nüfusunun yüzde 18'i Ermeni olmasına rağmen 1828 yılında kurulan Ermeni Vilayetinin Ermeni nüfusu, Rus idaresi tarafından özendirilen İran Ermenilerinin göçü sonucunda 20. yüzyıl başında yüzde 48'e ulaştı. Birinci Dünya Savaş1 esnasında ve sonrasında Osmanlı İmparatorluğundan mülteci olarak gelen Ermenilerle birlikte bu sayı yüzde 70'lere ulaştı. İran ve Türk kökenli halkın da bölgeyi terk etmesiyle beraber tedricen günümüzdeki Ermeni Cumhuriyeti'nin Ermeni çoğunluklu nüfusuna dönüştü. Ekim Devriminden Sosyalist düzene geçiş aşamasında 2 yıllık Erivan merkezli Ermenistan Demokratik Cumhuriyeti kurulmuş, Türk ve Rus ordularının senkronik işgaliyle bağımsızlığını kaybeden bu yapı, Aralık 1920'de SSCB'ye katılarak Ermenistan Sovyet Cumhuriyeti adını almıştır (Palabıyık ve Deveci, 2009:259).

SSCB'nin çöküşünden hemen önce Azerbaycan sınırlarına dâhil olmasına rağmen kahir ekseriyeti Ermenilerden oluşan Dağlık Karabağ (Nagornı Karabağ) bölgesi hakkında ihtilaf çıktı ve Karabağ Ermenilerinin isyanıyla burada ayrı bir cumhuriyet ilan ettiler. Azerbaycan sınırları içerisinde yer alan bu özerk bölge, SSCB'nin dağılması esnasında büyük bir çatışmanın nedeni haline geldi. Ağustos 1991'de bağımsızlığını ilan eden Ermenistan, Dağlık Karabağ ile Ermenistan arasında kalan Lâçin Koridorunu işgal ederek Dağlık Karabağ'1 fiilen ilhak etti. Bu gelişmeleri de kapsar bir biçimde her iki ülke arasındaki çatışma 1991-1994 tarihleri arasında tüm hızıyla devam etti. 1992'de altı yüzün üzerinde Azerbaycan Türkünün canına mal olan Hocalı soykırımı yaşandı (Uras, 1987:646). Buna mukabil Azerbaycan ve Türkiye Ermenistan'a ekonomik ambargo uyguladılar. Dağlık Karabağ'la birlikte yedi rayonu işgal edilen Azerbaycan'a destek olarak Türkiye, Ermenistan'la tüm ilişkilerini durdurdu ve sınırını tamamen kapattı. Topraklarının beşte biri Ermeni işgaline maruz kalmış bir ülke olarak Azerbaycan, yaklaşık otuz yıllık dönemde egemen bir devlet olma duygusunu hakkıyla yaşayamadı.

Tüm bu tarihsel perspektif açısından bakıldığında, Azerbaycan sınırlarını 1920 Kars Anlaşmasıyla kabul etmiş olan Türkiye'nin 1991-1994 yılları arasında cereyan eden Ermeni saldırıları döneminde gerekli diplomatik cevabı vererek topraklarını Ermenistan'a kapatmanın ötesinde Azerbaycan'a gerekli desteği veremediğini müşahede etmekteyiz. Zira o dönemde Türkiye, bir yandan faili meçhul cinayetlerle, diğer yandan PKK terörüyle meşgul edilmiş ve SSCB'nin çökmesinden sonra Orta Asya ve Kafkasya'da varlığ çalışılmıştı. Hâlbuki Sovyet Rusya'nın çöküşünden sonra iki kutuplu dünyada stratejik önemi azaldığ 1 düşünülen Türkiye'nin önüne müthiş ufuklar açılmıştı. Bugünkü güç ve vizyona sahip bir Türkiye, o zaman için mümkün olsaydı bugün karşılaştı̆̆ımız bölgesel sorunlar ve trajediler yaşanmayabilirdi. Ne var ki, tarihi konjonktür Türkiye ile Türk dünyasını birbirinden koparmak için adeta bir hançer gibi sınırları biçimlendirilen Ermenistan'ın işlevini yerini getirmesine yeterince müsaade etmiştir. 
Öte yandan uluslararası toplum Azerbaycan'ın topraklarının işgal altına alınmış olunduğunu tescil etti ve Dağlık Karabağ çatışmalarının yaşandığı 1993 senesinde Birleşmiş Milletler Güvenlik Konseyi (BMGK) üst üste dört karar aldı. Bu kararlar sırasıyla aşağıdaki gibi özetlenebilir;

1. 3 Nisan 1993 işgalinin akabinde Ermeni birliklerinin Kelbecer ve diğer işgal ettiği bölgelerden çıkmasını dikte eden 30 Nisan 1993 tarihli ve 822 sayılı kararı,

2. Ermenistan'ın Ağdam'dan çıkmasını talep eden 29 Temmuz 1993 tarih ve 853 sayılı kararı,

3. Ermenistan'ın Füzuli, Cebrayıl ve Kubadlı'dan çekilmesini amir 14 Ekim 1993 tarih ve 874 sayılı karar,

4. Ermenistan'ın Zengilan'1 derhâl tahliye etmesini öngören ve 822, 853 ve 874 sayılı kararları teyit eden 884 sayılı karar (BMGK 822 sayılı kararı 29.04.1993, BMGK 853 sayılı kararı 30.07.1993, BMGK 874 $\begin{array}{lllllll}\text { say1l1 karar1 } 14.10 .1993 & \text { ve } & \text { BMGK } 884 & \text { sayıl1 } & \text { karar1 } & 12.11 .1993 .\end{array}$ http://www.un.org/Docs/scres/1993/scres93.htm (Erişim tarihi 19.11.2020).

Ne var ki, BMGK'nin aldığı ve tüm tarafları bağlayıcı nitelik taşıyan tüm bu güçlü kararlara rağmen gelinen son noktada Ermenistan, Dağlık Karabağ'ı ele geçiriyor ve burada gene Ermenistan'a rağmen ve Ermenistan'ın kabul etmediği özerk bir cumhuriyet kuruluyor. Bunun haricinde ilçe konumunda değerlendirebileceğimiz 7 rayon da işgal edilmiş statüsünü sürdürüyor. Üç yıllık çatışmalarda 20 bin Azerbaycan Türkü katlediliyor ve bir milyona yakın Azerbaycanlı yerinden yurdundan edilerek "göçmen" (kaçkın) durumuna düşürülüyor. Maalesef ki bu dönemde Azerbaycan henüz yeni kurulmuş bir devlet olarak nizami bir orduya sahip bulunmamaktaydı. Türkiye ise kendi içindeki derin sorunlardan dolayı çevresini göremeyecek durumdaydı. Ebulfez Elçibey dirayetli duruşuyla Rus askerlerini ülkesine sokmamış, Rus nüfusun ülkeyi terk etmesini sağlamış, Bağımsız Devletler Topluluğu'na (BDT) üye olmamış ve diğer Türk cumhuriyetlerinden farklı olarak bağımsızlığı için savaşmış eşsiz bir liderdi. Ancak özellikle Türkiye'yle yakın ilişkiler kurması Rusya'yı ve Güney Azerbaycan'la bütünleşme arzusu İran'ın tepkisini çekti.

Bu şartlar altında iki devleti Bişkek'te Mayıs 1994'te bir araya getiren AGIT'in MINSK Grubu, statükoyu korumak ve çözümsüzlüğü çözüm olarak sunmaktan başka bir gayesi olmayan eş başkanlardan müteşekkil taraflı bir aktör olarak sahne aldı (Nesibli, 2000:63). Öyle ki en fazla Ermeni diasporasına sahip olan ve Ermenistan'ın GSMH'nın yüzde 48'ini sağlayan Amerika, yine ikinci en büyük diasporaya sahip olan ve Ermenistan ekonomisinin yüzde 16'sını tedarik eden Fransa ve Ermenistan'1 arka bahçesi ve kirli oyunlarının şahsiyetsiz bir kuklası olarak gören Rusya MİNSK Grubu'nun karar verici aktörleridir. Haliyle bu aktörlerin tamamı kayıtsız şartsız Ermenistan'ın arkasındadır ve hiçbirinin uluslararası hukuku hâkim kılmak gibi bir kayg1s1 yoktur.

1994 Bişkek Anlaşmasından günümüze bu problem, MiNSK Grubu tarafindan "dondurulmuş bir ihtilaf" (frozen conflict) haline getirilmiş ve konunun çözülmemesi için her türlü gayret gösterilmiştir. Müteakip yıllarda Rusya, Azerbaycan'a Rus birlikleri yerleştirmek, İran ve Türkiye sınırını Rus askerlerinin korumasını empoze etmek ve Hazar petrollerinden gelir elde etmek gibi politikalar izlediği için Azerbaycan'ı kendisinden oldukça uzaklaştırdı. Öte yandan 1997'den itibaren Azerbaycan dış politikasının rotasını büyük oranda ABD’ye yöneltti. Bu yönelimin en somut meyvelerinden birisi, 29 Ekim 1998'de Türkiye, Azerbaycan, Gürcistan, Kazakistan ve Türkmenistan'ın Bakü-Tiflis-Ceyhan petrol boru hattı projesine açık destek veren Ankara Deklarasyonu'nun imzalanması oldu. Türkiye ile Azerbaycan arasındaki ilişkiler "bir millet iki devlet" anlayışı ile derin dostluk ilişkileri içinde sürdürülmektedir.

30 Ağustos 1991 tarihinde bağımsızlığını ilan eden Azerbaycan Cumhuriyeti'ni 9 Kasım 1991'de tanıyan ilk devlet Türkiye oldu. Azerbaycan'la 14 Ocak 1992'de imzalanan protokolle diplomatik ilişki kurularak Başkonsolosluk olarak görev yapan Temsilcilik, Büyükelçilik düzeyine yükseltildi. Halen Azerbaycan'da Bakü T.C. Büyükelçiliği ile Nahçıvan ve Gence Başkonsoloslukları faaliyet göstermekte olup, Azerbaycan'ın ise Ankara'da Büyükelçiliği'nin yanı sıra İstanbul ve Kars'ta Başkonsoloslukları bulunmaktadır (Sarıahmetoğlu, 2016:201). Bu dönemde yüzden fazla anlaşma, protokol ve çeşitli işbirliği anlaşmaları imzalanmıştır. Ekonomi, ticaret, eğitim, kültür konularında ve bilimsel alanlarda iki ülke arasında yapılan birçok anlaşma halen yürürlüktedir. Ermenistan'a sınır kapılarını 1993 yılında kapatan Türkiye, bu siyasetinden ancak Dağlık Karabağ özgürlüğünü kazandığında vazgeçeceğini belirtmiştir. Avrupa Birliği'nin zorlamasıyla 10 Ekim 2009 tarihinde İsviçre'de imzalanan Türkiye-Ermenistan protokolü ilişkilerde kısa süreli gerginliğe neden olsa da daha sonra Türkiye'nin “Önce Karabăg, sonra sinırlar" politikasına dönmesi (Sarıahmetoğlu, 2016: 98), ilişkileri normal seyrine oturttu. Bu tarihten itibaren Karabağ'1 işgalden kurtarmak için mücadele eden Azerbaycan, en büyük yatırımını orduya ve savunmaya yaptı. Bu süreçte Türkiye, Azerbaycan ordusunun eğitiminden teçhizatına kadar- kurulmasında çok kapsamlı bir katkı sağladı. 
Ermenistan, işgal ettiği toprakları terk etmek bir yana zaman zaman yeni alanlar kazanmayı da hedeflemiştir. Ancak son on yıllık dönemde bu işgalin Ermenistan'a faturasının çok ağır olduğunu fark eden Ermeniler de çıkmıştır. Bu kesimler ya savaşarak ya da bir anlaşma zemininde en azından bu toprakların bir kısmının geri verilebileceğini düşünmüşlerdir. Bu anlayışın bir uzantısı olarak 29 Kasım 2007 tarihinde Azerbaycan Dışişleri Bakanı Elmar Memmedyarov ve Ermenistan Dışişleri Bakanı Vartan Oskanyan Madrid'de Minsk Grubu Eşbaşkanları ile görüşmüşlerdir (Sarıahmetoğlu, 2016:111). Bu görüşmelerde Eşbaşkanlar taraflara güç kullanmama ilkesi çerçevesinde yeni bir barış planı sunmuşlardır. Bu plana daha sonra Madrid Prensipleri denilmiştir. Azerbaycan ve Ermenistan tarafından 1lımlı karşılanan bu plan, sunuluşundan sonra da üzerinde yapılan düzenlemelerle devam etmiştir. Bu prensiplere göre; Dağlık Karabağ’ın çevresindeki işgal edilen topraklar boşaltılacak, Laçin koridoru açılacak, göçmenler yurtlarına geri dönecek, barış gücü işlevini yerine getirecek, uluslararası güvence sağlanacak, Dağlık Karabağ Ermenilerine teminat verilerek kendilerini idare etme hakkı tanınacak, Dağlık Karabağ’ın hukukî statüsünün belirlenmesi için inisiyatif kullanılacaktır.

Madrid prensiplerinin uygulanmasının ilk aşamasında (ABD, Rusya, $\mathrm{AB}$ ve Türkiye) güçlerin temsil rolünün çok önemli olduğu görülmektedir. Azerbaycan ve Ermenistan'dan önce bölgede menfaatleri olan devletlerin anlaşması gerekmektedir. Madrid prensiplerinde iki taraf da en az tavizle nasıl en fazla kazanç elde edilebilir hesabını yapmaktadır. Sarkisyan'ın Karabağ'dan çekilmesi karşı1ığında Karabağ'ın kendi kaderini tayin hakkını talep etmesi bunun göstergesidir. Burada temel problem, Rusya'nın krizin ne tamamen Azerbaycan ne de tamamen Ermenistan lehine çözülmesini istememesidir. Zira Azerbaycan topraklarını tamamen özgürleştirirse bölgede daha bağımsız politikalar uygulayabilecek ve Türkiye ile daha fazla işbirliği sahası bulabilecektir. Öte yandan Ermenistan bu kıskaçtan kurtulursa $A B D$ ve $A B$ ile daha fazla yakınlaşma eğilimi yansıtabilir. $\mathrm{Bu}$ durum kendini Kafkasya'nın tek hâkimi olarak gören ve Yakın Çevre Doktrini bağlamında bölge dışı güçleri denklem dışında tutmaya çalışan Rusya'nın politikalarına muvafık düşmeyecektir. Ne var ki ABD ve AB Rusya ile zaman içinde oluşan enerji bağımlılığından kurtulmak ve Hazar Havzasındaki petrolün Gürcistan ve Azerbaycan üzerinden alternatif yollarla taşınmasını öncelemek istemektedir. Diğer yandan Rusya, gittikçe güçlenen enerji zengini Azerbaycan'1 kaybetmek istememekte ve bu nedenle Azerbaycan'ı tamamen karşısına alacak politikalar uygulamak hususunda çekingen davranmaktadır.

\section{DONDURULMUŞ BİR İHTILAF OLARAK ERMENISTAN - AZERBAYCAN ÇATIŞMASININ NÜKSEDİŞi}

2016 yılının Nisan ayında Azerbaycan ve Ermenistan arasında cephe hattı boyunca artan gerilim, Karabağ'da Azerbaycan ordusuna gerçekleştirilen bir harekâtla görünür hale geldi. Ermenistan ordusunun verdiği zararlar sonucu cephe bölgesinde yeniden askerî operasyonlar başladı. Defalarca yapılan çağrılara rağmen, Ermenistan ateşkese uymak istemedi. Savaşlarda kaybettiği toprakları geri almak adına sivil halka ateş açtı. Azerbaycan Ordusu'nun karş1lık vermesi ile düşman çok fazla kayıp verdi ve geri çekildi. Ermenistan birlikleri 1 Nisan 2016'dan 2 Nisan'a geçen gece Azerbaycan'ın tüm cephe hattı boyunca yoğun ateş açtılar. Ermeniler bununla sadece Azerbaycan ordusuna yönelik bir saldırı değil, aynı zamanda uluslararası anlaşmaları ihlal ederek sivil halka karşı askerî suç kapsamında da bir ihlal gerçekleştirdiler. Temas hattının yakınında bulunan yerleşim birimleri, göçmen kasabaları Ermeni saldırılarına maruz kaldı. Sonuçta birçok sivil yaralandı, eğitim kurumları hasar gördü, evler yıkıldı, ciddi maddî hasar yaşandı. Azerbaycan silahlı kuvvetleri saldırıları önleyerek karşı darbelerle Ermeni birliklerini geri çekilmeye mecbur etti, birkaç stratejik mevkide kontrolü ele geçirdi. Ermenistan silahlı kuvvetleri çok sayıda asker ve teknik kayba uğradı. 5 Nisan 2016 saat 12.00'den itibaren Azerbaycan ve Ermenistan ordusunun temas hattında tarafların anlaşmasıyla harekât sona erdi. Uluslararası kamuoyunun tepkisi de bu süreçte ayrıca dikkat çekici idi. Bu kez Batı, konuya objektif yaklaşmaya çalıştı. Azerbaycan'ın toprak bütünlüğünü kabul edenlerin artması, birçok devletin adil bir tutum sergilemesi, yıllarca yapılan propagandaların sonucu olarak ortaya çıktı. AGİT Minsk Grubu Eşbaşkanları veya uluslararası teşkilatlar bu konuda yine yeterli olamadı (Akyeşilmen, 2013:241). Ancak Azerbaycan yönetimi sorunun barışçıl çözümü yönünde çabalarını sürdürmeye devam etti. Devlet Başkanı ve hükümet yetkilileri Karabağ konusunda pek çok zirve toplantısı yapmakta ve görüşmelerin yapıcı bir noktaya yönelmesi için gayret göstermektedirler. Aynı zamanda, ordunun savaş kabiliyeti geliştirilmekte, toprakların kurtarılması için ciddi adımlar atılmaktadır.

2018 yılına geldiğimizde nihayet Rusya'nın korktuğu olmuş, Ermenistan'ın Başbakanı olarak George Soros'un ve dolayısıyla AB'nin desteğini aldığı iddia edilen Nikol Paşinyan seçilmişti (Aras, 2017:103-104). Paşinyan iktidarı ele aldığ günden itibaren provokatif adımlara hız vermekle kalmamış, iki müttefikinden birisi olan Rusya'dan uzaklaşmaya başlamış, diğer müttefiki olan İran'la ilişkilerini tahkim etmiş ve kendine Avrupa ve Amerika'da yeni müttefikler aramaya başlamıştı. Haddi zatında Paşinyan'ın provokatif siyasetinin arkasında 
ABD ve Fransa'da mukim olan Ermeni diasporasının tahriki yatmaktaydı. Ermenistan'ın toplam gelirinin yaklaşık yüzde yetmişine karşıllk gelecek kadar destek veren diaspora Ermenileri, Ermenistan'da yoksulluk sınırın altında izole bir hayat yaşayan vatandaşlarını hiç düşünmüyorlardı. Nitekim yeni renkli devrimler peşinde koşan Paşinyan'ın savunma bakanı David Tonoyan ülkesinin yeni "Askeri Stratejik Vizyon belgesini”" 10 Haziran 2020 tarihinde açıkladı (Askeroğlu, 2020). Tonoyan, Yeni Stratejik Belge'nin asıl amacını, "düşmanın saldırı amaçlarını ve kapsamlı savaş başlatma isteğini kırmakla kalmayıp düşmanın savaşı yürütme olanağını ortadan kaldırmak", olarak vurguladı.

Ermenistan'ın askerî, siyasi ve ekonomik sorunlarını çözmesi için savunma pozisyonunu bırakarak saldırgan bir yaklaşım benimsemesi gerektiğini ileri süren bu deklarasyondan çok kısa süre sonra, 12 Temmuz Pazar günü Azerbaycan ile Ermenistan sınırında Ermeni birliklerinin Tovuz bölgesine saldırısıyla yaşandı. Türkiye, Ermenistan'ın saldırgan eylemlerine son vermesi çağrısında bulunarak Azerbaycan'a her türlü desteği vereceğini açıkladı. Rusya'nın verdiği yoğun silah desteğiyle cesaret kazanan Ermenistan, bu saldırısıyla Rusya'nın ve üyesi olduğu Kolektif Güvenlik Anlaşması Örgütünün (KGAÖ) kendisine olan desteğini ölçmeye çalışmaktadır. Buna ilaveten -Avrupa ve Soros destekli olduğu iddia edilen - hâlihazır Ermenistan hükümetinin, bu hamleyi askeri ve ekonomik olarak bağımlı olduğu Rusya'dan kurtulmak ve özellikle Fransa'ya yanaşmak için kullanacağı aşikârdır. Nitekim bu durum Fransa'ya arayıp bulamayacağı bir firsat penceresi sunmaktadır.

Libya'da ve Suriye'de Türkiye'yle ters düşmüş ama her iki durumda da kaybeden taraf olmaktan kurtulamamış bir aktör konumundaki Fransa, hem Kafkasya'da yer edinme ve hem de Doğu Akdeniz'de Yunanistan üzerinden hâkim bir pozisyona yükselme imkânını bulduğunu düşünmektedir. Buna ilaveten kendi derin iç problemlerini dışarıda güç göstererek çözmek, Macron'un AB liderliği hayalleriyle de örtüşmektedir. Ne var ki bu defa evdeki hesap çarşıya uymamış gibi görünmemektedir. Zira Ukrayna'da, Kırım'da, Belarus'ta çok ciddi sorunlar yaşayan, petrol fiyatlarının düşmesiyle ekonomik krizin girdabında debelenen ve Libya ve Suriye'de düştügü zor durumdan dolayı Türkiye'yle işbirliği zemini arayan Rusya'nın Azerbaycan'ı karşısına almaya yönelik bir tutum sergilediği söylenemez. Öte yandan Paşinyan, Rusya ile uyumlu çalışan bir aktör olmadığı için, yaygın kanaate göre, Rusya tarafından cezalandırılmaktadır. Ayrıca Azerbaycan da sahip olduğu jeopolitik ve milli güç potansiyeli açısından Rusya'nın karşısına alabileceği bir aktör değildir.

\section{ERMENISTAN - AZERBAYCAN ÇATIŞMASININ SAVAŞA DÖNÜŞMESİ}

Tüm bu minval üzere Azerbaycan, 27 Eylül Pazar günü Tovuz'a yapılan ikinci saldırıyı, -beklenenin aksinebasit birtakım misillemelerle geçiştirmeyi tercih etmemiştir. Bu konjonktürü akılcı bir stratejik temayülle değerlendirdiği anlaşılan Azerbaycan, üç farklı bölgeden temas hattına doğru ilerleyerek birbiri ardınca stratejik bölgeleri ele geçirmeye başlamıştır. 3427 metre rakıma sahip olan Murov Dağı düşmandan geri alınan ilk nokta olmuştur. Bir Yıldırım Harekâtı Operasyonu (Blitzkrieg) yerine zaten çok dağlık olan, otuz yıllık zaman diliminde mayınlanmış ve Rus usulü tahkim edilmiş sahayı SïHA ve uzun menzilli silahlarla yumuşatarak ilerlemeyi esas almıştır. Aksi takdirde yüksek dağların arasında yer alan vadilerle askerin ilerlemesi ya da savunma hattını kırmaya yönelik atılım yapması ciddi kayıplara yol açabilecektir. Bu tercih, haliyle harekâtın yavaş ilerlemesine yol açmaktadır. Özellikle kentlerin kuşatılarak ele geçirilmesi oldukça uzun bir zaman gerektirmektedir.

Öte yandan Ermeni saldırılarını Bakü-Ceyhan-Tiflis enerji hattına, Bakü-Tiflis-Kars demiryoluna ve Türkiye bağlantısını kuran tek karayoluna ve TANAP'ın Güney Kafkasya'daki başlangıç noktasına yönelik bir sabotaj olarak algılayan Türkiye, bu tecavüzle Azerbaycan'la arasında var olan tüm ulaşım ve iletişim imkânlarının kesilmesinin hedeflendiğini düşünmektedir. Zaten 1994 Bişkek Ateşkesinden bugüne Azerbaycan ordusunun güçlendirmesi için tecrübe paylaşımı başta olmak üzere eğitim, teçhizat desteği veren Türkiye, bu defa Suriye ve Libya'da kullandığı İHA ve SİHA'larını da Azerbaycan'a vermiştir. Bununla yetinmeyen Türkiye, ancak kardeş bir ülkeye yapılabilecek çok değerli bir katkıda daha bulunarak Barış Planı ve Zeytin Dalı Operasyonlarında uyguladığı stratejiyi "iki devlet bir millet”" anlayışına bağlı olarak Azerbaycan'la paylaşmıştı.

Otuz yıldır Karabağ sevdası ile yetişen genç kuşaklarını cepheye süren Azerbaycan hızla ilerleyişini sürdürür ve işgal altındaki topraklarını bir bir özgürleştirirken MİNSK Grubu ve Rusya, Ermenistan'a desteklerini 11, 18 ve 26 Ekim tarihlerinde ateşkes ilan ettirerek gösterdiler. Zira sözde insani amaçlarla cenaze ve esir değişimi için yapılan bu ateşkesler, Ermenilerin lojistik tahkimat yapmaları ve daha fazla sivil öldürmelerinden başka bir amaca hizmet etmedi. Öyle ki ilk iki ateşkeste Gence, üçüncüsünde Berde merkez alınarak pek çok kent ve köy Ermeni füzelerinin hedefi oldu ve doksanın üzerinde Azerbaycan vatandaşı sivil bu saldırılarda canını kaybetti. Haliyle bu noktada şu soruyu sormak oldukça makul ve anlamlı hale geliyor: Ermenistan başının ezileceğini ve işgal ettiği toprakları peyderpey kaybedeceğini bildiği halde Cenevre Sözleşmesine göre savaş ve insanlık suçu 
niteliği taşıyan bu cürümleri niçin işliyor? Bu nedenlerin başında Azerbaycan halkının kendi devletine duyduğu güven duygusunu yok etmek olduğu anlaş1lyyor. Zira burada Azerbaycan devleti, Ermenistan'ın bir saat geçmeden misket bombaları kullanarak ihlal ettiği ateşkeslerle kendi halkı ve sınırlarını korumaktan aciz bir devlet gibi gösterilmekte ve devletle milletin arası açılmak istenmektedir. İkinci neden, Azerbaycan devletinin uluslararası camiaya güvenini yitirmesini sağlamak ve topraklarını özgürleştirse bile siyaseten ve hukuken geri alabileceği konusundaki ümidini kırmaktır. Üçüncüsü uluslararası medya ve camianın sessiz kalışından hareketle Azerbaycan'a yalnızlığını hissettirmektir. Bunun yanı sıra Azerbaycan'ı tahrik etmek suretiyle Ermenistan'ın kendi topraklarına ve sivil hedeflere saldırmasını sağlayarak Kolektif Güvenlik Anlaşması gereğince Rusya'yı Ermenistan'ın yanında savaşa dâhil etme çabası da bir diğer neden olarak görülmektedir. Öte yandan Türkiye'nin garantör olduğu Nahcivan'a saldırarak Türkiye'nin de muharip güç olarak sahada yer alması istenmektedir. Haddi zatında en temel neden, savaşın şirazeden çıkıp sivil alanlara yansımasını bahane ederek uluslararası toplumun bölgeye müdahalesini sağlamak ve böylelikle bölgesel ve hatta daha geniş çaplı bir savaşın fitilini ateşlemektir. Zira Ermenistan, tek başına Azerbaycan'la baş edemeyeceğini görmüş, Rusya, AB ve ABD desteği olmadığı takdirde ezici ve aşağılayıcı bir hezimete duçar olacağını anlamış durumdadır.

Savaşın sahada sürdüğ̈̈ esnada farklı bir muharebe meydanı da istihbarat ve medya alanında, algı operasyonları üzerinden şekillendirilmekteydi. Bir kere Ermenistan-Azerbaycan arasındaki çatışmalar "savaş" olarak adlandırıldı. Malum olduğu üzere savaş, iki devlet arasında ve sınırların ötesinde gerçekleşir. Hâlbuki burada bir proje devlet ve PKK'nın devletleşmiş hali olan Ermenistan'ın işgal ettiği topraklar üzerinde Azerbaycan tarafindan yürütülen bir "terörle mücadele operasyonu" söz konusudur. Bu durumu -sürpriz bir biçimde- Putin de kabul etmektedir. Bir televizyona verdiği mülakatta, "niçin Kolektif Güvenlik Anlaşmasını yürürlüğe koyup Ermenistan'a yardım etmiyorsunuz?" sorusuna tarihi bir cevap vermiştir: "Çatışmalar Azerbaycan toprakları üzerinde cereyan ediyor, bizim müdahalemizi gerektiren bir durum yok" (BBB News, 2020). Verdiği bu cevapla Putin, hem Dağlık Karabağ ve yedi rayonun Azerbaycan toprağ olduğunu kabul etmekte ve hem de Ermenistan'ın işgalci bir terör örgütü olduğunu -zımnen de olsa- itiraf etmektedir. Bununla birlikte Dağl1k Karabă̆ ve Ermeni işgalindeki yedi bölge/ilçe/rayon için uluslararası medyada "ihtilaflı topraklar" nitelendirmesi yapılmaktadır. Hâlbuki Birleşmiş Milletler Güvenlik Konseyi (BMGK) 1993 yılında yayınlandığı dört kararla bu bölgenin -üzerinde hiçbir ihtilaf olmaksızın- Azerbaycan toprağı olduğunu deklare etmiştir.

Ek olarak Ermenistan, Türkiye'nin F-16'ları ve askerleriyle bizzat sahada olduğu yalanını yaymaya çalışmış ve hatta daha ileri giderek Türkiye'nin Suriye Milli Ordusuna mensup 300 cihatçıyı bölgeye gönderdiği iftirasını atmaktan geri durmamıştır. Cephede çarpışan yüz binden fazla muvazzaf askeri ve görev almak için cephe gerisinde emir bekleyen yüz bine yakın gönüllüye sahip olan Azerbaycan'ın böyle bir ihtiyacı bulunmadığı aşikârdır. Bunun ötesinde misket bombaları kullanarak ve sahanın ötesinde muharip olmayan insan ve yerleşim birimlerine saldırarak savaş suçu işleyen Ermenistan, farklı savaşlara ait görüntüleri Azerbaycan'ın sivilleri vurması gibi gösterebilmektedir. Nitekim bu kabil iftiraların alıcısı çoktur. Hâlihazırda Azerbaycan cephesinde Türk medyasının dışında hiçbir ana akım uluslararası medya kuruluşu olmamasına rağmen karşı tarafta Avrupa ve ABD medyası Azerbaycan'ın en küçük savaş ihlalini yakalayıp haber yapmak için firsat kollamaktadır. Gence ve Berde başta olmak üzere onlarca insanın canına mal olan Ermeni saldırılarını görmeyen Avrupa medyası, Azerbaycan aleyhine yalan haber yapma konusunda oldukça heveskâr görünmektedir. Bu yalanlar arasında en revaç bulanı, Türkiye'nin Azerbaycan'la birlikte hareket edip 1915'te başlattıkları sözde Ermeni Soykırımını bugün tamamlamak için adım attıkları istikametindeki olmuştur. Ne var ki, 1991-1994 arasında hayatını kaybeden 20 bin Azerbaycan Türkü, kendi topraklarında göçmen konumuna düşen bir milyon civarındaki masum sivil Türk, Batı medyası için haber değeri taşımamaktadır.

Peki, söz konusu terörle mücadele operasyonunda hangi ülke kimin yanında ve niçin pozisyon almaktadır? Bölge ülkelerinden başlarsak en ikircikli ve anlaşılması güç tutuma sahip olan devletin İran olduğunu kolayca görebilmekteyiz. İran öncelikle, bölge politikalarında Türkiye ile "zero-sum" (sıfırlı toplamlı) bir ilişki üzerinden tavrını belirlemektedir. Yani, Türkiye'nin kazancı benim kaybım diye özetlenebilecek bu yaklaşımla Türkiye'ye zarar verecek her adımı tereddütsüz ve hiçbir ahlaki ilkeye dayanmadan atan bir aktördür İran. Haliyle Azerbaycan'ın Hazar Havzasında ve Kafkasya'da enerji kaynaklarını bağımsız olarak kullanan ve Avrupa'ya alternatif enerji hatları sunabilen bir oyuncu olarak var olmasını istemeyen İran, haddi zatında Azerbaycan'ın bir devlet olarak varlığını sürdürmesine karşıdır. Buna ilaveten ülkesinde 30 milyonun üzerinde Azerbaycan Türkü ve Türkmen nüfusun iskân edildiği ve bizim "Güney Azerbaycan" olarak adlandırdığımız bölgeye sahip olan İran, bir gün Türkmençay Anlaşmasından önce olduğu gibi Azerbaycan'la kendi topraklarının yarısını kapsayan Türk bölgesinin birleşme ihtimalinden korkmaktadır.

İran, tüm devlet kurumlarına işlemiş Türk düşmanlığının bir yansıması olarak Ermenistan ve Yunanistan gibi proje devletlerin en yakın müttefiki olagelmiştir. Ermenistan'la 44 kilometrelik bir sınıra sahip olan İran, 
Ermenistan'ın dünyaya açılan tek kapısı ve nefes borusu konumunda yer almaktadır. Maalesef ki İran, savaş esnasında bu sınırı kapatmadığı gibi hava sahasını da Rusya'ya açarak Ermenistan'ı tüm hayati ihtiyaçları için köprü olmuştur. Haşdi Şabi üzerinden Irak'1, Hizbullah üzerinden Lübnan'1, Bedir Tugayları üzerinden Suriye'yi, Husiler üzerinden Yemen'i kana bulayan İran, PKK ve PJAK üzerinden Ermenistan'a destek vermektedir. Nitekim Suriye ve Lübnan'daki PKK'lı Ermeniler, İran'ın destek ve teşvikiyle Ermenistan'a taşımıştır. Bu tavrıyla din ve mezhebin (İslam'ın ve Şiiliğin) Fars'ın takiyeci ve kirli siyasetine alet olmanın ötesinde bir anlam taşımadığını gösteren İran, Ermenistan'ın en büyük müttefiki olarak aynı zamanda Türkiye ve Azerbaycan'la da yakın ilişkiler kurmak arzusundadır.

Ermenistan'la benzer bir devlet yapısına ve dünya görüşüne sahip olan İran'ın kendi iç bütünlüğünü nasıl koruyacağ 1 ve bölgede nasıl inandırıcı bir aktör haline dönüşeceği merak konusudur. Ne var ki İran kendi içinde bu ikilemi yaşarken kendisine en büyük destek İsrail ve ABD'den gelmiştir. İsrail lobisinin desteğiyle ABD, İran'a uygulanan silah ambargosunu tamamen kaldırmış, bölgenin kana bulanması ve istikrarın bozulması rolünde İran'ın daha fazla başarı sağlaması bu sayede teminat altına alınmıştır. Bu gerçeği gören Azerbaycan askeri, İran'la Ermenistan arasındaki ortak bölgeyi ele geçirerek bu iki terör devletini birbirinden ayırmıştır.

Rusya’nın en büyük korkusu ise Azerbaycan'ın Ermeni işgaline uğrayan topraklarını özgürleştirmesiyle Güney Kafkasya'daki belirleyici rolünü kaybetme ihtimalidir. Zira Rusya bölgede ne Ermenistan'in ne de Azerbaycan'ın güçlü olmasını ister. Bilakis her iki devletin, ancak Rusya'nın çözebileceği derin krizlerle boğuşması, bu ülkenin statükoyu koruma adına en büyük arzusudur. Sorun çözüldüğünde Azerbaycan enerji konusunda Rus bağımlılığından kurtulmak isteyen Avrupa için ciddi bir alternatif olacaktır. Türkiye'nin siyasi çözüme yönelik olarak kurulması muhtemel olan masada kesinlikle olmaması gerektiğini savunan Dışişleri Bakanı Lavrov, Anadolu Türkleriyle Azerbaycan Türklerini bir araya getirmemeye yönelik Lenin ve Stalin politikalarına sıkı sıkıya bağlı olduğunu göstermektedir. Zira Azerbaycan'la birleşerek Orta Asya'ya açılan bir Türkiye, bölgede dengeleri bozacak muazzam bir jeopolitiğe sahip olacaktır. Bu kâbusu yaşamamak için Lavrov Planı adıyla sözde bir barış teklifi ortaya konulmuş, bu plana göre -Ermenistan'la Dağlık Karabağ arasında ulaşımı sağlayan kara yolunu bünyesinde barındırdığı için stratejik öneme sahip olan - Laçin ve Zangezur koridorları hariç diğer rayonların Azerbaycan'a verilmesi ve Dağlık Karabağ'ın özerkliğini korunması teklif edilmiştir. Bu planın bir gereği olarak Nahcivan'la Azerbaycan ve Azerbaycan'la Türkiye, aralarında hiçbir kara parçası olmayan coğrafyalar olarak kalmaya devam edecektir.

Sonuç itibarıyla bölgeye dönük her türlü kirli siyasetinde kullanabileceği kukla devlet olarak Ermenistan’1 kaybetmek istemeyen Rusya, ekonomisi, siyaseti ve ordusuyla gittikçe güçlenen ve Türkiye'yle özel ilişkilere sahip olan -Orta Asya'nın kapısı ve güney sınırının koruyucusu - Azerbaycan'ı tam olarak karşısına almaya da cesaret edememektedir. Ne var ki Azerbaycan, İran ve Türkiye sınırına Rus birliklerini konuşlandırmayı kabul etmemekte, Rusya ile ortak platformlarda yer almak istememekte ve Rusya'yı rahatsız ettiğini bilmesine rağmen $A B$ ve $A B D$ ile ilişkilerini geliştirerek sürdürmektedir. Azerbaycan'ı nevi şahsına münhasır kılan boyutlarından birisi de İsrail'le kurduğu ilişkilerdir. İsrail'den aldığ gelişmiş ve modern silahlara mukabil bu ülkeye petrol veren Azerbaycan, kendi sınırları içerisinde kadim Yahudi topluluklarına ev sahipliği yapmaktadır. İsrail ise Azerbaycan'a verdiği destekle bölgede kaos ve anarşinin odağı olan İran'ı kontrol altına aldığını ve sınırladığını düşünmektedir.

İhtilafin tarafı olarak göreceğimiz diğer iki ülke ise, AGİT'in 1992'de oluşturduğu ve 1994'te ateşkeste arabulucu konumunda yer alan MiNSK Grubu'nun iki başkanı Fransa ve ABD'dir. Bu iki ülke Ermenistan diasporasını barındıran ve ülkenin finansmanını sağlayan aktörler olarak taraflıdırlar ve dolayısıyla adil ve hakkani karar almaları beklenemez. Bu ülkelerden Fransa'yı ele aldığımızda -aynen Yunanistan'a yaptığı gibikrizi firsat bilerek Ermenistan'a silah sattığını görüyoruz. AB'nin liderliğine oynayan bir güç olarak ordusunu ön plana çıkarmaya çalışan Fransa, dış politikada aktif rol üstlenerek kendi iç çekişmelerini unutturmaya çalışmaktadır. Önümüzdeki yıl yapılacak seçimlerde başarı şansını düşük gören Macron, İslam'ın tüm dünyada krizde olduğu mealinde açıklamaları ve Charlie Hebdo dergisinin İslam peygamberine yönelik hakaretamiz karikatürlerinin okullarda müfredata konması ve kamu binalarında sergilenmesine cevaz veren yaklaşımlarıyla ülkesindeki radikal laik ve faşist kesimlerin desteğini alma arzusunu taşımaktadır.

İslam ve yabancı düşmanlığı üzerinden oy devşirmeye çalışan Macron'un Kelbecer ve Lâçin Koridoru da dâhil olmak üzere Karabağ'da Kanada ve İsviçre'yle beraber bölgede bulunan altın ve diğer değerli madenleri yağmalayarak yasadışı gelir elde ettiği biliniyor. ABD ise her iki tarafi müzakere masasına çağırarak, çözümsüzlük üreterek Türkiye ve Rusya'yı Karabă̆ üzerinden askeri bir çatışmaya itmeye çalışıyor. Diğer yandan Rusya'nın yakın çevre politikası kapsamında daha önce çokça giremediği bölgeye daha kalıcı bir biçimde nüfuz etmek isteyen ABD, Şusa'da bir askeri üs kurma arayışında. Bu arayışın bir yansıması mahiyetinde MINSK Gurubu olarak tarafları 30 Kasımda bir araya getiren ABD, krizin siyasi yollarla 
çözümlenmesi gerektiğini ve İskandinav ülkelerinden oluşan bir barış gücünün bölgeye konuşlandırılmasının elzem olduğunu belirtiyor.

Başkan'ın Ulusal Güvenlik Danışmanı O’Brian, Türkiye'nin bölgeye İslamcı teröristleri soktuğu yönünde ellerinde deliller olduğundan hareketle kurulacak müzakere masasında ve teşkil edilecek barış gücünde Türkiye'nin olmaması gerektiğinin altını çiziyor. 3 Kasımda yapılacak olan seçimlere odaklanan ABD’nin daha sonra çıkacak tabloya bağlı olarak MİNSK Grubunu genişletip içine Türkiye'yi de alabileceği iddia ediliyor (Zorlu, 2020). Azerbaycan ordusunun savaşı bitirecek son darbe olarak Lâçin koridoruna yaklaşması üzerine Moskova, sahada aktif olarak bulunmamakla birlikte Ermenistan'a vereceği askeri ve ekonomik desteği artıracağını bildiriyor. Bölge ülkeleriyle diplomatik temasa geçen İran ise, Astana Sürecine benzer bir biçimde içinde İran, Rusya, Türkiye ve Azerbaycan'ın olduğu MïNSK Grubuna alternatif bir diyalog zemini oluşturmaya çalıştı̆̆ da gözlerden kaçmıyor. Tüm bu müzakere çaba ve zeminlerine Azerbaycan Devlet Başkanı İlham Aliyev'in cevabı ise gayet net (TRThaber, 2020);

\section{“Íçinde Türkiye'nin olmadı̆̆ bir müzakere masası kurulamaz. Azerbaycan kendi topraklarını özgürleştirme hususunda kimseyle müzakere etmez. Müzakere sadece Ermenistan'ın Azerbaycan topraklarından ne zaman ve nasıl çekileceğini kesin bir dille izah eden bir takvim vermesi üzerinden inşa edilebilir."}

Nitekim bu çerçevede Azerbaycan ordusunun Hankendi'ne ulaşmasına birkaç kilometre kala Azerbaycan'ın güney sınırında bir Rus helikopterinin Azerbaycan tarafından yanlışlıkla vurulduğu haberinin ve Hazar civarında sebebi bilinmeyen patlamaların üst üste gelmesiyle bir panik yaşandığı bir ortamda Rusya-Azerbaycan ve Ermenistan arasında bir anlaşmaya varıldığı ilan edildi (Cura ve Rehimov, 2020). Öncelikle nihai anlaşmadan ziyade bir ateşkes anlaşması olduğu belirtilen mutabakat metnine göre ordular 10 Kasım 2020 gece yarısı itibarıyla bulundukları yerde kalacaklar. Karabağ'da temas hattına 1960 adet hafif silahlı olmak üzere 90 zırhlı araç ve personelinden ibaret Rus askerinden oluşan bir barış gücü 5 yıl süreyle konuşlanacak ve Azerbaycan toprakları içerisinde muhtemelen Türkiye'nin de olduğu bir barış denetleme merkezi kurulacak. Gene anlaşmaya göre, Ermeni askeri 15 Kasıma kadar Kelbecer, 20 Kasıma kadar Ağdam ve 1 Aralık tarihine kadar Laçin rayonunu boşaltacaklar. Boşaltılan bölgelere sayısı 1 milyonu bulan kaçkın, Birleşmiş Milletler denetiminde peyderpey yerleştirilecek. Ermenistan ile Karabağ arasında bağlantı sağlayan stratejik Laçin koridoru 5 kilometrelik bir genişlikte Rus Barış Gücü tarafından kontrol edilmekle beraber Nahcivan'la Batı Azerbaycan arasında ulaşımı mümkün kılacak koridor ise Rus istihbarat Örgütü FSB tarafından denetlenecek (Euronews, 2020).

Öncelikle Azerbaycan'ın zaferi olarak takdim edilen anlaşmadan hemen saatler sonra Rus askerlerinin 22 uçakla Karabağ'a intikali ve Karabağ'ın savaş esnasında Azerbaycan tarafindan ele geçirilmemiş dörtte üçlük bölümünün akıbetinin belirsizliği kuşkuyla karşılanmaktadır. Öte yandan Türkiye'nin Karabağ'da yer almayacağının netleşmesi, Ermenistan'ın boşaltacağı Karabağ topraklarına ve tüm temas hattına Rusların yerleşecek olması gibi nedenlerle kamuoyu ciddi bir endişe ve hayal kırıklığı yaşamaktadır. Anlaşma metninde Türkiye'nin çözümün tarafı olduğuna dair hiçbir ibare yer almamaktadır. Laçin ve Nahcivan koridorlarından sivil ve asker geçişlerinin nasıl ve hangi esaslara göre gerçekleşeceği hususu belirsizliğini korumaktadır. Buna mukabil anlaşma, Nahcivan üzerinden Türkiye'nin Kafkasya' yla arasında yeniden komşu olması ve yüz yıl önce Lenin tarafından Anadolu Türkleri ve Azerbaycan Türklerini birbirinden koparma politikasını sonlandırması bakımından olumlu karşılanmışır. Ancak bu koridorun denetimi konusunda -Rus varlığının süresi ve yetkisi bakımından- belirsizlik söz konusudur. Bu belirsizlik olumlu yönde aşılırsa Türkiye ile Türk dünyası arasında stratejik, ekonomik ve siyasi anlamda jeopolitiği değiştirecek bir irtibat sağlanmış olacaktır. Öte yandan içinde Fransa ve ABD’nin de olduğu MINNSK Grubu'nun devre dışı bırakılmış olması önemli bir gelişmedir.

Rusya'nın Ermenistan'ın garantörü konumunda yer almasının Ermeni ihlallerini engelleyeceği ve geri çekilme dâhil anlaşmanın uygulanmasını kolaylaştıracağı yolunda yaygın bir kanaat mevcuttur. Bu anlaşmayla Türkiye ile Rusya arasındaki işbirliğinin Libya ve Suriye'de yeni bir pozitif ivme kazanacağı da iddia edilmektedir. Ne var ki Suriye'de Barış Pınarı Harekâtı dokuzuncu gününde Rusya ve ABD tarafından teklif edilen bir ateşkesle durdurulmuş, ancak yapılan anlaşmaya bu iki ülkenin uymaması neticesinde Fırat'ın doğusu ve batısındaki YPG/PKK teröristlerinin faaliyetlerini artırarak sürdürdükleri görülmektedir. Benzer bir biçimde Libya'da oldukça başarılı olan Vatiyye ve Tarhune operasyonlarından sonra varılan uzlaşma neticesinde Türkiye destekli Trablus ordusunun durdurulmasıyla Sirte ve Cufra hattında Rusya ve Hafter'in güçlenmesi, terör ve anarşinin artması ve ülkenin bölünmesine yönelik beklentinin arttı̆̆ bir ortam oluşmuştur.

Tüm bu kötümserlik içeren yorumlara karşı bazı kesimler, bu anlaşmanın sadece ateşkese yönelik bir metin olduğu ve nihai uzlaşmanın Türkiye ve Rusya arasında sürdürülecek müzakereler neticesinde şekilleneceğini 
ifade etmektedirler. Nitekim 12-14 Kasım tarihlerinde Türkiye'ye bir Rus heyet gelmiş ama müzakere neticesinde henüz net bir açıklama yapılmamış ve sadece görüşmelerin süreceği istikametinde bir deklarasyonla yetinilmiştir. Bu durum her iki tarafın nihai uzlaşmadan oldukça uzak olduğu yönünde bir kanaatin oluşmasına yol açmıştır. Muhtemeldir ki Rusya'nın Karabağ'ın büyük bir kısmında söz sahibi olması, bu bölgenin statüsünün netleşmemiş olması ve Hankendi civarında Azerbaycan ordusunun durdurulmasıyla yirmi bin civarında Ermeni askerinin imha edilmekten kurtulması, Ermenistan'1 cesaretlendiren ve Karabağ meselesinin henüz nihayete ermediğini gösteren alametler olarak algılanmasını da beraberinde getirmiş oldu.

\section{SONUÇ: ERMENISTAN - AZERBAYCAN SAVAŞININ DÜNYA DÜZENINE ETKİLERİ}

Her ne olursa olsun Şuşa'nın özgürlüğüne kavuşturulması ve akabinde yaşananlar Güney Kafkasya'daki jeopolitik denklemi tersyüz etmekle kalmadı Türkiye-Azerbaycan arasında gittikçe derinleşen yeni bir ilişki türünü ortaya çıkarttı. Öyle ki daha önce eşi görülmemiş bu işbirliğinin tüm Kafkasya ve Orta Asya'ya yayılma potansiyeli de oldukça fazla görünmekte. Buna ilaveten Çin'i ortak, Rusya'yı düşman gören bir siyasi gelenekten gelen Joe Biden'ın ABD Başkanı olması ve Rusya'nın Gürcistan, Ukrayna, Kırım ve Belarus başta olmak üzere pek çok problemle kuşatılmış bir atmosferde bulunması Türkiye için yeni bir jeopolitik ufkun doğmasına imkân hazırlamaktadır. Tam da bu noktada yeni ABD yönetiminin Azerbaycan'la kıskanılacak bir ilişki modalitesi yakalayan Türkiye ile Karadeniz ve Kafkasya'ya nüfuz etme yönelimine girmesi söz konusuyken öte yandan ABD ile Trump döneminde yakaladığı ivmeyi kaybedecek olan Rusya'nın bölgeye harici güçleri sokmamak için Türkiye ile birlikte hareket etme güdüsü güçlenecektir. Nitekim söz konusu anlaşmanın zamanlaması da Biden dönemine kadar ön alma ve inisiyatif oluşturma gayreti olarak değerlendirilebilir.

Çatışmanın tarafları açısından değerlendirildiğinde Rusya, Kafkasya'nın yegâne hâkim gücü olarak hakem ve aracı rolünü güçlendirdi. MİNSK Grubu başta olmak üzere bölge dışı güçlerin müdahalesini önledi. Karabağ' da hiç savaşmadan ciddi bir toprak parçası kazanmış oldu. Avrupa ve ABD'ye yakın ve Soros tarafından fonlandığı söylenen Paşinyan'a gerekli dersi vermiş oldu. Türkiye ile Suriye ve Libya'da işbirliğini derinleştirebilecek yeni bir ilişki tarzına ivme kazandırıldı. Türkiye açısından bakıldığında -yüz yıllık aradan sonra- Güney Kafkasya'da Azerbaycan'la komşu oldu. Kafkasya ve Orta Asya ile stratejik ittifak oluşturabilecek bir ivme yakaladi. Azerbaycan'la ilişkilerinde daha önce sahip olmadığı derinlikte bir işbirliği ve ittifak dinamiği yakaladı. Hatta bu ittifakın ilk somut göstergesi olarak -Rusya ile imzalanması muhtemel olan bir mutabakat zaptıyla beraberAzerbaycan'da çözümün bir parçası haline gelmiş oldu. Sorunun en önemli öznesi olan Azerbaycan'a baktığımızda yaklaşık otuz yıl önce SSCB'den ayrıldığı ve henüz düzenli bir milli ordusunun olmadığı bir dönemde kaybettiği topraklarını yeniden özgürleştirerek egemen devlet olmanın gurunu ilk kez yaşamış oldu. Şimdiye kadar üzerinde taşıdığı ezilmiş̧lik, yenilmiş duygusu ve zaaflarından kurtularak kendine güvenini yeniden kazand1. Karabağ özlemiyle yetiştirilen kuşaklar ve bugünün hayaliyle yaşayan vatanından edilmiş kaçkınlar nihayet beklentilerinin önemli ölçüde gerçekleştiği zafer atmosferini yeniden yaşadılar. Nihayet Ermenistan da işgal, zulüm ve büyük güçlere dayanarak sürdürdüğü şımarık saldırganlığının bedelini çok ağır bir biçimde ödedi ve Paşinyan'ın tabiriyle "kendilerine çok acı veren" bir anlaşmaya imza atmak zorunda kaldı. Ciddi kaos ve anarşinin yaşandığı, hükümet binası ve parlamentonun işgal edildiği ve ateşkesin şiddet eylemleriyle protesto edildiği Ermenistan'da Paşinyan'ın yerini Rus yanlısı bir hükümete devretmesine kesin gözüyle bakılmaktadır.

Sonuç olarak, Azerbaycan'la Ermenistan arasındaki bu krizin vuku buluş tarzını (modus vivendi) ve gelişim aşamalarını (modus operandi), şekillenmekte olan yeni bir dünya düzeni üzerinden bakmak gerekecektir. Zira 1989'da Berlin Duvarı'nın yıkılması, 1990'da Doğu Avrupa'da sosyalizme karşı sivil direnişin başlaması ve nihayet 1991'de Sovyet Rusya'da Komünist Parti'nin parçalanmasıyla nihayete eren iki kutuplu dünyanın yerine yenisinin inşası sürecinde geçiyoruz. Tüm dünyada etkin olan pandemi de bu süreçte bir katalizör rolü oynamakta. Bu geçiş sürecinde dünyada hegemon bir gücün olmaması, hâlihazır düzeni meşrulaştırmaya yarayan BM, NATO, AGIT ve Avrupa Konseyi gibi uluslararası kurumların işlevini tamamen yitirmesi, uluslararası hukukun artık işlemez hale gelmesi geçtiğimiz asra dair çözümlenmemiş ve makalemizin başında belirttiğimiz donmuş krizlerin yeniden gündeme gelmesini mümkün k1lıyor. Haliyle yüzyıldır çözüm bulunmayan sorunların aşılmasının yegâne yolu olarak çatışma ve savaşlar görülüyor. Buna ilaveten kurulacak yeni dünyanın belki de en önemli stratejik coğrafyasını Orta Asya ve Kafkasya bölgesi oluşturuyor. Zira bu inşa sürecinin $\mathrm{ABD}$ ve Çin arasında yer yer sıcak savaşa dönüşebilecek bir kapışma olmadan tamamlanmayacağı biliniyor. Bu bakımdan Azerbaycan topraklarında yaşananlar, Kafkas Baharı olarak da anılan sosyal ve siyasi hareketleri başlatacak ve şekillendirecek bir dönüm noktası olma potansiyelini taşıyor. 


\section{KAYNAKLAR}

AKYEŞILMEN, Nezir (2013), "Dağlık Karabă̆ Sorunu: Çözüm Araylşında Minsk Grubu ve Bölgesel Aktörlerin Rolü”, Barışı Konuşmak: Teori ve Pratikte Çatışma Yönetimi (Ed. Mehmet Fatih Öztarsu), ODTÜ Yayınc1lık, Ankara, ss.239-260.

ARAS, İlhan (2017), “Avrupa Birliği’nin Dağllk Karabağ Sorunundaki Rolü”, Avrasya Etüdleri Dergisi, S.51(1), ss.95-122.

ARI, Tayyar (2013), Uluslararası İlişkilere Giriş, Marmara Kitap Merkezi (MKM) Yayınları, Bursa.

ASKEROĞLU, Sabir (2020), “Ermenistan'ın Yeni Saldırı Stratejisi”, İran Araştırmaları Merkezi (İRAM), 16.07.2020, https://iramcenter.org/ermenistanin-yeni-saldiri-stratejisi/ (Erişim Tarihi: 11.11.2020).

BBC NEWS (2020), "Dağllk Karabağ: Times'a göre Ermenistan, Rusya'dan Müdahele Etmesini İsteyebilir", BBC News, 01.10.2020, https://www.bbc.com/turkce/haberler-dunya-54368058 (Erişim Tarihi: 02.11.2020).

BUDAK, Ali (2019), Osmanlı Modernleşmesi, Gazetecilik ve Edebiyat, Bilge Kültür Sanat Yayınları, İstanbul, 2. Bask1.

CAMPBELL, David (1992), Writing Security: United States Foreign Policy and the Politics of Identity, University of Minnesota Press, Minneapolis - USA.

CAMPBELL, David (1998), Writing Security: United States Foreign Policy and the Politics of Identity, University of Minnesota Press, Minneapolis - USA.

COX, Robert (1987), Production, Power and World Order - Social Forces in the Making of History, Columbia University Press, New York.

CURA, Ali ve REHIMOV, Ruslan (2020), “Ermenistan'da Rus Askeri Helikopteri Düşürüldü: 2 Ölü”, Anadolu Ajansı, $\quad$ 09.11.2020, https://www.aa.com.tr/tr/azerbaycan-cephe-hatti/ermenistan-da-rus-askerihelikopteri-dusuruldu-2-olu/2037638 (Erişim Tarihi: 13.11.2020).

DEDEOĞLU, Beril (2008), Uluslararası Güvenlik ve Strateji, Yeniyüzyıl Yayınları, İstanbul, 2. Bask1.

DEDEOĞLU, Beril (2018), Uluslararası Strateji ve Güvenlik, Yeniyüzyıl Yayınları, İstanbul, 4. Baskı.

EURONEWS (2020), “Dağglık Karabăğ'da Çatışmaları Sonlandıran Anlaşmanın Maddeleri Neler?”, Euro News, 10.11.2020, https://tr.euronews.com/2020/11/10/ermenistan-ile-azerbaycan-n-anlast-g-dagl-kkarabag-anlasmas-n-n-maddeleri-neler (Erişim Tarihi: 11.11.2020).

FIERKE, Karin M. (2007), Critical Approaches to International Security, Polity Press, Cambridge.

HETTNE, Björn (2007), "Global Governance and World Order: Pax Americana or Pax European Ur", European Union and New Regionalism (Ed. Mario Telshgate), Ashgate Publisher, Farnham - UK.

NESIBLİ, Nesip (2000), “Azerbaycan ve Moskova-Erivan-Tahran İtifakının Jeopolitik Kuşatması”, Stratejik Analiz, S.1(4), ss.61-72.

PALABIYIK, Mustafa Sencer ve DEVECİ BOZKUŞ, Yıldız (2009), "Turkish - Armenian Relations (19182009)", The Armenian Question, Basic Knowledge and Documentation (Der. Ömer Engin Lütem), Terazi Publishing, Ankara, ss.255-299.

SARIAHMETOĞLU, Nesrin (2016), "Karabağ Sorununun Çözüm Sürecinde Türkiye ve Rusya", Marmara Türkiyat Araştırmaları Dergisi, S.3(2), ss.93-119.

TRTHABER (2020), “Aliyev'den Karabağ'da Uzun Süreli Ateşkes İçin Taahhüt Şartı”, TRT Haber, 22.10.2020, https://www.trthaber.com/haber/dunya/aliyevden-karabagda-uzun-sureli-ateskes-icintaahhut-sarti-525219.html (Erişim Tarihi: 04.11.2020).

URAS, Esat (1987), Tarihte Ermeniler ve Ermeni Meselesi, Belge Yayınları, İstanbul. 
ZORLU, Kürşat (2020), "Türkiye AGİT Minsk Grubu Eşbaşkanlığını İşte Böyle Elinden Kaçırmış!", Habertürk, 11.10.2020, https://www.haberturk.com/yazarlar/prof-dr-kursad-zorlu/2831555-turkiye-agitminsk-grubu-esbaskanligini-iste-boyle-elinden-kacirmis (Erişim Tarihi: 06.11.2020).

822 sayılı Birleşmiş Milletler Genel Kurulu Kararı (Karar Tarihi: 29.04.1993).

853 sayılı Birleşmiş Milletler Genel Kurulu Kararı (Karar Tarihi: 30.07.1993).

874 sayılı Birleşmiş Milletler Genel Kurulu Kararı (Karar Tarihi: 14.10.1993).

884 sayılı Birleşmiş Milletler Genel Kurulu Kararı (Karar Tarihi: 12.11.1993).

http://www.un.org/Docs/scres/1993/scres93.htm (Erişim Tarihi: 19.11.2020). 